\title{
THE SYNDROME OF THE INFERIOR VENA CAVA: A CASE REPORT
}

\author{
Bojan Mladenović1,2, Nikola Mladenović3, Vesna Brzački ${ }^{1,2}$
}

\begin{abstract}
The inferior vena cava (IVC) collects blood from the abdomen and lower extremities, climbs the retroperitoneum and enters into the right atrium of the heart. Obstruction of IVC can be caused by venous thrombosis, a neoplasm that exerts external pressure on a vein or infiltrates the vein and by pregnancy. Obstruction of the IVC causes edema of the lower extremities, dilatation of the veins of the lower part of the abdomen which serve as collaterals. In the diagnosis of these disorders, it is necessary to perform detailed laboratory tests, ultrasound of the abdomen, computerized tomography, and finally cavography. In this way, the etiology of the obstruction is determined, the place and degree of obstruction, collateral circulation is detected and eventual surgical reconstruction is planned.
\end{abstract}

Acta Medica Medianae 2021;60(3):61-66.

Key words: inferior vena cava, ascites, retroperitoneal tumor

\author{
${ }^{1}$ University of Niš, Faculty of Medicine, Department of Internal \\ Medicine, Niš, Serbia \\ 2University Clinical Center Niš Clinic of Gastroenterology and \\ Hepatology, Niš, Serbia \\ ${ }^{3}$ Institute of Cardiovascular Diseases of Vojvodina, Sremska \\ Kamenica, Serbia
}

Contact: Bojan Mladenović

81 Dr Zoran Djindjić Blvd., 18000 Niš, Serbia

E-mail: bojan.mladenovic@medfak.ni.ac.rs

\section{Introduction}

The inferior vena cava (IVC) is the largest vein that carries blood from the abdomen and lower extremities. It begins behind the right common iliac artery, climbs the retroperitoneum, passes through the diaphragm, and enters the right atrium.

The iliac vein, lumbar vein, right ovarian or spermatic vein, renal veins, right suprarenal vein, phrenic vein, and hepatic veins flow into it. It is connected with many peritoneal and retroperitoneal structures. In the front, separated by the peritoneum, it crosses the right common iliac artery, anterior lymph nodes, right spermatic artery, transverse colon, with branches of the aortic plexus of the sympathetic, the "root" of the mesentery, duodenum and pancreas.
On the ascending pathway, the IVC enters the groove for vena cava (sulcus venae cavae), on the underside of the liver. Here, the liver caudate lobe separates it from the portal vein.

On the right side, the IVC borders the peritoneum, ureter, kidney, liver, paraaortic lymph nodes, and aorta on the left. It lies posteriorly on the psoas muscle and the lumbar, vertebral musculature, right vertebral and renal arteries. After passing through the diaphragm, it is enveloped by the pericardium before it enters the right atrium. The inferior vena cava valve is on the endocardial side of the IVC junction.

Obstruction of the inferior vena cava is most often caused by the movement of a blood clot from the femoral or iliac veins or a neoplasm. Less common causes of obstruction are external pressure from the abdominal aortic aneurysm, inflammatory reactions around or in the inferior vena cava, hepatic vein dilation and thrombosis.

Neoplasms can cause external pressure on the inferior vena cava or can infiltrate the external wall. Neoplasms may continue progressing and growing within one of the branches of the inferior vena cava leading to its obstruction (1-11).

IVC compression or obstruction causes severe leg edema, dilated abdominal veins, which serve as collaterals. If obstruction affects the renal veins, a syndrome similar to nephrosis occurs, or renal vein thrombosis (12-14).

Morgagni, Sappey, and Dumontpallier were the first to notice IVC occlusion and extensive collateral development.

Based on the obstruction and collateral development levels, we differ among infrarenal obstruction, middle obstruction, and upper IVC obstruction (15). 


\section{Case Presentation}

Patient P.S., born in 1966, unemployed, was admitted to the Clinic of Gastroenterology and Hepatology, University Clinical Center Niš with diagnosed ascites.

The problems started two months before the admission when she noticed that her stomach was swollen, that she was pale and that she got tired easily. Since then, she has been having nausea and dull pain in the cap. In the last week before the admission, her legs were very swollen. She reported an allergy to Bactrim. Regarding the family history, she stated that her mother died of rheumatoid arthritis and her father died of a stroke.

At the reception, the patient was conscious, oriented in time, space and to people, afebrile, eupneic, mobile, of average osteo-muscular constitution and moderately nourished, with pale skin and

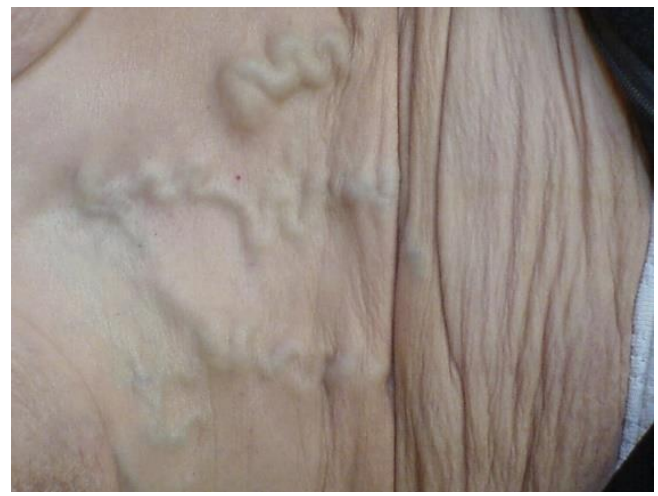

Figure 1. Collateral blood flow 1

Laboratory findings - sedimentation 2, leukocytes 15.6, lymphocytes 0.172, monocytes 0.99, granulocytes 0.73 , erythrocytes 4.61 , hemoglobin 80 , hematocrit 38 , thrombocytes 441 , glycemia 6 , urea 8.8, creatinine 63.4, AST 179 ALT 221.5, total proteins 68, albumin 38.5, cholesterol 2.51, triglycerides 1.12, urate 299.3, ALP 772.5, LDH 1842.2, gamma GT 153.3, amylase 126.6, blood group 0, Rh negative, Alpha-fetoprotein $1.8 \mathrm{ng} / \mathrm{l}$, coagulation status normal, IgA $4.5 \mathrm{~g} / \mathrm{l}, \mathrm{IgM} 3.79 \mathrm{~g} / \mathrm{l}$, IgG 18.81 $\mathrm{g} / \mathrm{l}$, antinuclear, antimitochondrial, antismooth muscle, antiparietal antibodies negative, anti HCV negative, HbsAg negative, ascites punctate - serum-ascites albumin gradient (SAAG) $<0.97 \mathrm{~g} / \mathrm{dL}$, in sediment erythrocytes and rare round cells, seeded ascites antibiogram negative. ECG - nomogram. Radiography of the heart and lungs - finding normal. Findings of a cardiologist, hematologist and gynecologist - normal.

Abdominal echo - liver of normal position, rounded, echogenic, inhomogeneous. Gallbladder without calculus and of normal wall thickness. The pancreas was of normal position, shape and size, echogenic. In the space from the pancreas head mucous membranes, gave the impression of a more serious patient. Her head was of normal configuration without sore spots. The nose was passable. The tongue was movable, uncoated. The bulbs were symmetrical, mobile, pupil reaction to light was preserved, accommodation normal. The neck was cylindrical without enlarged glands. The thyroid gland was movable, normal in size. The thorax was symmetrical, cylindrical, moving with respiration, breath sounds were diminished basally, and the cardiac action was rhythmic, the tones were clear, there was no murmur, BP $125 / 95 \mathrm{mmHg}$. Abdomen above the chest level, symmetrical, with signs of free fluid so that the abdominal organs were not palpable. Collateral blood flow was visible on the anterior abdominal wall (Figures 1 and 2). Kidney succussion and palpation were negative. Limbs - with lower leg and upper leg swelling without varicose veins.

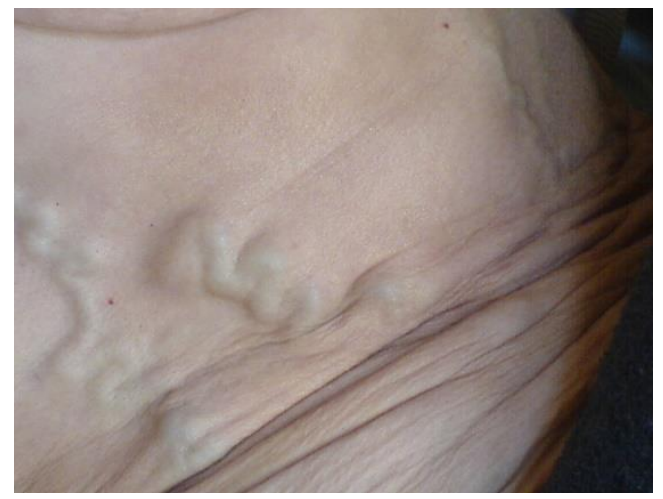

Figure 2. Collateral blood flow 2

towards the liver hilus and down along the IVC, there was an inhomogeneous change measuring $174 \times 42 \mathrm{~mm}$ and compressing IVC. The spleen was normally positioned, shape and size, homogeneous. The kidneys were normally positioned, shape and size and corticomedullary index with no downtime. Ascites and pleural effusion were present on the left.

Histogram analysis of regions of interest showed heterogeneous liver structure with a standard deviation (SD) of 4.8 to 5.1 (Figure 3), while isoechogenic ascites structure was with an SD of 4.0.

Leg vein Color Doppler - dilated femoral and iliac veins. The saphenous vein was dilated. Superficial veins were dilated. There were no thrombotic changes in the observed veins. The arteries of both legs were with normal flows, with no signs of stenosis. Interstitial edema was present.

Intrahepatic vein Color Doppler - intrahepatic vein measure was normal. There were no signs of their obstruction.

IVC Color Doppler - in the middle part of the flow, joint vein compression was observed, and Color Doppler registered a very reduced blood flow. 
Abdominal computed tomography - the liver was diffusely altered. A hypodense change relative to the liver parenchyma was registered behind the liver, which extended downwards along the IVC.
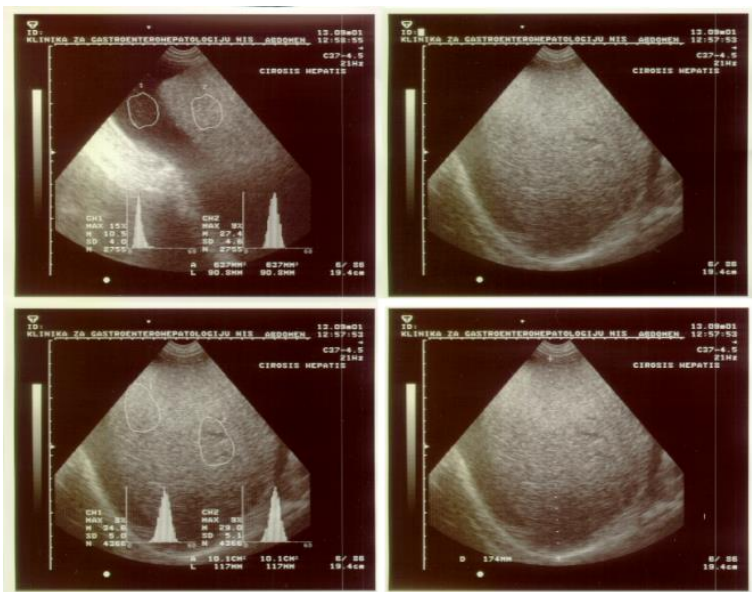

Figure 3. Echo of the abdomen

Cavography - cavography was performed with the right transfemoral approach. The right common iliac vein (civ) was of normal contours and passable. There were no signs of overflow into the left civ, which was a sign of its occlusion. IVC of reduced lumen at the height of $L 4$ and $L 5$, while
After the contrast application, it was stained significantly less than the surrounding parenchyma, more pronounced cranially, where it got a mosaic appearance (Figure 4).

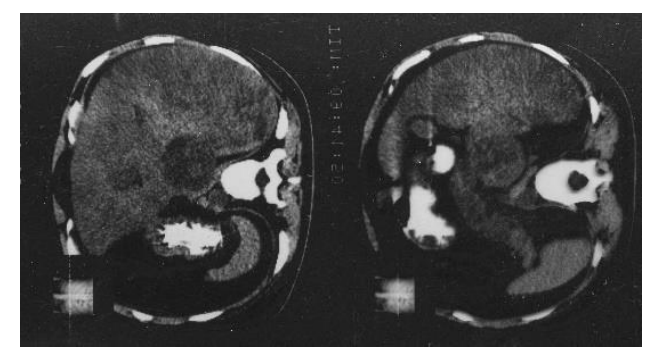

Figure 4. Computed tomography of the abdomen

from L3 proximally the IVC lumen was not displayed. Venous drainage took place through collateral veins - vv. lumbales ascendens. Reconstruction of the IVC was performed immediately before the right atrium (Figures 5 and 6 ).

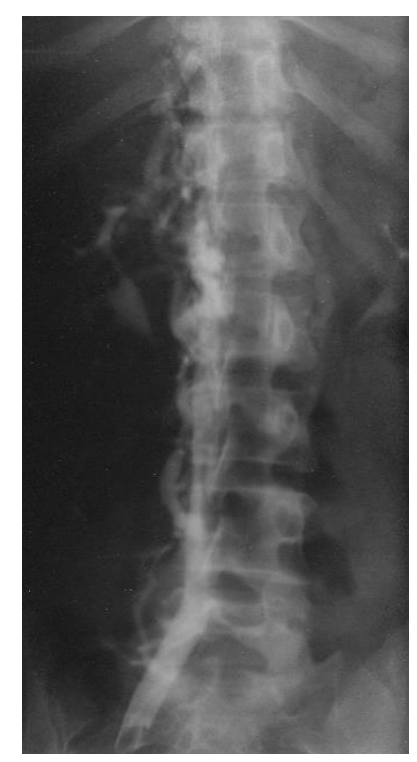

Figure 5. Cavography 1

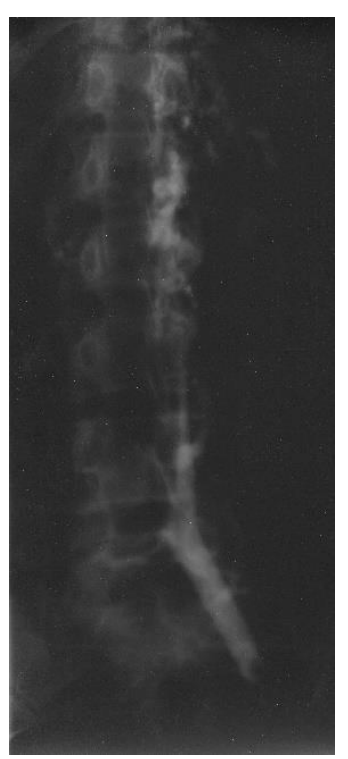

Figure 6. Cavography 2 
During the surgical reconstruction, the material was obtained that was histologically processed and leiomyosarcoma was verified (Figure 7).

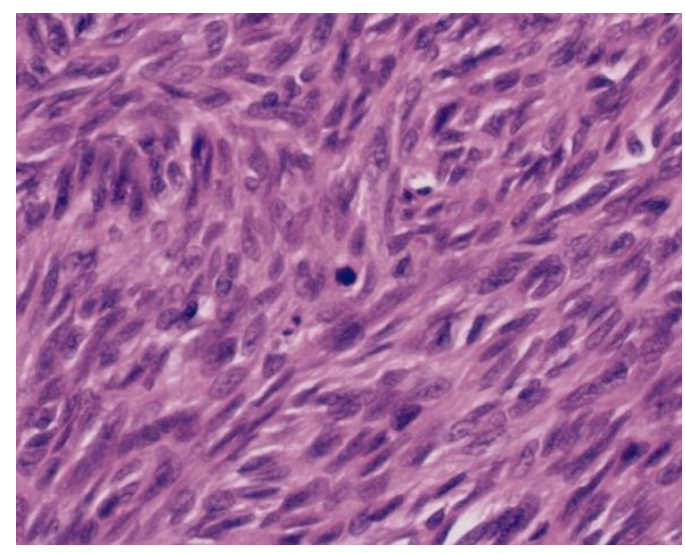

Figure 7. Leiomyosarcoma

\section{Discussion}

The inferior vena cava is the largest vein that carries blood from the abdomen and lower extremities. It climbs the retroperitoneum. It is connected with many peritoneal and retroperitoneal structures. Based on the obstruction levels, we differentiate among infrarenal obstruction, middle obstruction and upper IVC obstruction. Depending on the cause, obstructions can be caused by an intrinsic or extrinsic factor.

Tumors and metastatic changes in the liver should be considered in the differential diagnosis.
Echo and MSCT of the abdomen are helpful in this differentiation. In these findings, we do not see changes in the liver that would justify IVC compression, although the compression is at the middle level of vein flow (1-4).

Tumor of the right kidney with IVC thrombosis could be the reason for IVC syndrome, but then we would expect the development of nephrotic syndrome and ultrasound and MSCT should show the changes that would be clearly determined as a tumor-altered right kidney (8).

IVC syndrome could also occur in varicose altered femoral and iliac veins from where embolus could originate. Color Doppler of femoral and iliac veins should indicate the existence of varicose veins with thrombotic masses.

Aortic abdominal aneurysm too, though less frequently, can cause IVC compression. An ultrasound finding of the abdominal aorta would certainly be sufficient to detect aneurysm.

Budd-Chiari syndrome could also be the cause for the development of IVC syndrome. In the differentiation, the Color Doppler of the hepatic veins would be used to detect their obstruction.

Abdominal and retroperitoneum echography show no signs of an inflammatory process in the retroperitoneum, but an expansive change that compresses the IVC. This finding is also confirmed by MSCT. Also, no endoluminal process associated with IVC occlusion is observed.

Pregnancy could also, although rarely, cause IVC syndrome, but the patient was not pregnant.

In the presented patient, the reason for obstruction was leiomyosarcoma as an expansive extraluminal retroperitoneal tumor process. Other retroperitoneal expansion processes could also cause compression (Table 1) (12-15).

Table 1. Expansive processes of the retroperitoneum

\begin{tabular}{||c|c|c||}
\hline Tumor origin & Malignant & Benign \\
\hline \hline Mesenchymal & Liposarcoma & Lipoma \\
\hline & Leiomyosarcoma & Rhabdomyoma \\
\hline & Rhabdomyosarcoma & Fibroma \\
\hline & Fibrosarcoma & Fibromatosis \\
\hline & Malignant fibrous histiocytoma & Lymphangioma \\
\hline & Haemangiopericytoma & \\
\hline Vascular & Angiosarcoma & Neurilemmoma \\
\hline & Lymphangiosarcoma & \\
\hline Neurogenic & Malignant schwannoma & \\
\hline & Neurofibroma & Ganglioneuroma \\
\hline Sympathetic nervous origin tumors & Neuroblastoma & \\
\hline & Ganglioneuroblastoma & \\
\hline & Malignant paraganglioma & Benign teratoma \\
\hline & Extra-adrenal & \\
\hline & Pheochromocytoma & \\
\hline & Malignant teratoma & \\
\hline & Embryonal carcinoma & Seminoma \\
\hline
\end{tabular}


IVC obstruction causes severe leg edema, dilation of the lower abdomen veins that serve as collateral blood flow, as well as ascites.

In the diagnosis of such disorders, in addition to laboratory tests, it is necessary to do a detailed ultrasound examination of the abdomen and retroperitoneum, as well as exam the abdomen by computed tomography or magnetic resonance imaging. Certainly, cavography is inevitable to determine the reason and degree of obstruction, observe collateral blood flow and plan surgical reconstruction.

\section{Conclusion}

Free fluid in the abdomen, ascites, as well as collateral circulation on the anterior abdominal wall with lower extremity edema can also be caused by IVC compression. The reason for such obstructions can also be retroperitoneum tumor processes, which can, with their growth, compress the IVC, and even invade the wall by spreading per continuitatem.
1. Ruiz CS, Kalbaugh CA, Browder SE, McGinigle $\mathrm{KL}$, Kibbe MR, Farber MA et al. Operative strategies for inferior vena cava repair in oncologic surgery. J Vasc Surg Venous Lymphat Disord 2020;8(3):396-404. [CrossRef] [PubMed]

2. Clark MR, Khaja MS, Banathy AK, Wilkins LR. Images in Vascular Medicine. Multivessel obstruction and treatment in a patient with retroperitoneal leiomyosarcoma. Vasc Med. 2020;25(3):278-80. [CrossRef] [PubMed]

3. Nakajima S, Narita $S$, Sato $H$, Igarashi $R$, Nara T, Kanda $S$ et al. Advanced Adrenocortical Carcinoma with Vena Caval Tumor Thrombus Treated with Extended Surgery and Subsequent Chemotherapy. Hinyokika Kiyo. 2019;65(10):397-402.

[CrossRef] [PubMed]

4. Ferraris $M$, Callegaro D, Barretta F, Fiore M, Radaelli S, Stacchiotti $S$ et al. Outcome of iliocaval resection and reconstruction for retroperitoneal sarcoma. J Vasc Surg Venous Lymphat Disord. 2019;7(4):547-56. [CrossRef] [PubMed]

5. Murakami N, Arai Y, Takagawa Y, Okuma K, Takahashi $\mathrm{K}$, Inaba $\mathrm{K}$ et al. Inferior vena cava syndrome caused by retroperitoneal fibrosis after pelvic irradiation: A case report. J Gynecol Oncol Rep. 2018; 27:19-21. [CrossRef] [PubMed]

6. Balraj P, Kabbani L, Mathews J, Tinney F Jr, Schwartz $S$, Kwon D et al. Epithelioid Hemangioendothelioma Presenting as Inferior Vena Cava Obstruction Diagnosed Using an Endovascular Thrombectomy Device. Ann Vasc Surg. 2017;40:294.e7-294.e9. [CrossRef] [PubMed]

7. Changal $\mathrm{KH}$, Altaf SS, Raina A. A man with dilated superficial abdominal veins: A clinical presentation of non-Hodgkin lymphoma. J Intern Med. 2016;7(3): 222-4. [PubMed]
8. Kametaka $\mathrm{H}$, Makino $\mathrm{H}$, Ishikawa $\mathrm{T}$, Hatada $\mathrm{K}$, Higashidani K, Hasegawa A. Extended resection for a huge retroperitoneal malignant paraganglioma-a case report. Gan To Kagaku Ryoho. 2013;40(12):2460-2. [PubMed]

9. Tseng YC, Wu ST, Chao TK, Wu CJ, Chau T, Yang SS. A giant non-functional adrenocortical carcinoma presenting with acute kidney injury. Int Urol Nephrol. 2014;46(6):1101-5. [CrossRef] [PubMed]

10. Coppa J, Citterio D, Cotsoglou C, Germini A, Piccioni F, Sposito C. Transhepatic anterior approach to the inferior vena cava in large retroperitoneal tumors resected en bloc with the right liver lobe. Surgery. 2013;154(5):1061-8. [CrossRef] [PubMed]

11. Quinones-Baldrich W, Alktaifi A, Eilber F, Eilber F. Inferior vena cava resection and reconstruction for retroperitoneal tumor excision. Vasc Surg. 2012; 55(5):1386-93. [CrossRef] [PubMed]

12. Kapur S, Paik E, Rezaei A, Vu DN. Where there is blood, there is a way: unusual collateral vessels in superior and inferior vena cava obstruction. Radiographics. 2010;30(1):67-78. [CrossRef] [PubMed]

13. Caso J, Seigne J, Back M, Spiess PE, Pow-Sang J, Sexton WJ. Circumferential resection of the inferior vena cava for primary and recurrent malignant tumors. J Urol. 2009;182(3):887-93.

[CrossRef] [PubMed]

14. Okur N, Inal M, Akgül E, Binokay F. Case report: Pedunculated leiomyosarcoma of the inferior vena cava. Tani Girisim Radyol. 2003;9(1):78-80. [PubMed]

15. Smillie RP, Shetty M, Boyer AC, Madrazo B, Jafri SZ. Imaging evaluation of the inferior vena cava. Radiographics. 2015;35(2):578-92. [CrossRef] [PubMed] 
Prikaz bolesnika

UDC: $616.146-007.272$

doi:10.5633/amm.2021.0309

\title{
SINDROM DONJE ŠUPLJE VENE: PRIKAZ SLUČAJA
}

\author{
Bojan Mladenović1,2, Nikola Mladenović3, Vesna Brzački, ${ }^{1,2}$ \\ ${ }^{1}$ Univerzitet u Nišu, Medicinski fakultet, Katedra za internu medicinu, Niš, Srbija \\ ${ }^{2}$ Univerzitetski klinički centar Niš, Klinika za gastroenterologiju i hepatologiju, Niš, Srbija \\ ${ }^{3}$ Institut za kardiovaskularne bolesti Vojvodine, Sremska Kamenica, Srbija \\ Kontakt: Bojan Mladenović \\ Bulevar dr Zorana Đinđića 81, 18000 Niš, Srbija \\ E-mail: bojan.mladenovic@medfak.ni.ac.rs
}

Vena cava inferior (VCI) prikuplja krv iz abdomena i donjih ekstremiteta. Penje se retroperitoneumom i ulazi u desnu pretkomoru srca. Opstrukcija VCI može biti uzrokovana trombozom vene, neoplazmom, koja vrši spoljni pritisak na venu ili infiltrira venu i trudnoćom. Opstrukcija VCI uzrokuje izrazite edeme nogu, proširenje vena donjeg dela trbuha, koje služe kao kolaterali. U dijagnostici ovakvih poremećaja, potrebno je sprovesti detaljne laboratorijske pretrage, ultrazvučni pregled abdomena, kompjuterizovanu tomografiju i potom kavografiju. Tako se određuju etiologija opstrukcije, mesto i stepen opstrukcije, uočava se kolateralni krvotok i planira se eventualna hiruška rekonstrukcija.

Acta Medica Medianae 2021;60(3):61-66.

Ključne reči: donja šuplja vena, ascites, retroperitonealni tumor 